\title{
The influence of public opinion on the external policy of Spain in the XXI century
}

UDC [94:327-32.019.51]《2000/2019» DOI https://doi.org/10.24195/2414-96162020.1.10

Matlai Liubava Serhiivna

PhD in Historical Sciences,

Assistant of the Department of Political

Science and International Relations

Lviv Polytechnic National University

Mytropolyta Andreja str., 5, Lviv, Ukraine

\begin{abstract}
The purpose of the article is to disclose the influence of public opinion on the formation and implementation of Spain's foreign policy, to consider the interaction of foreign policy makers. The application of the principle of historicism made it possible to investigate specific historical foreign policy situations and their perception by the public opinion of the parliamentary monarchy. In accordance with the principle of dynamics and development, the evolution of the formation of Iberian public opinion is reflected. For the first time, some theoretical works by Spanish scholars on public opinion on foreign policy and international relations are presented and characterized. The peculiarities of public opinion in a separate average European country with global interests are investigated. It can be argued that the interest of ordinary Spaniards in the sphere of foreign policy and interstate relations has not been a priority for a long time. The first government cabinets of democratic Spain changed the philosophy of foreign policy, forms and means of implementation of international politics, developing a communicative function, explaining the purpose and objectives of foreign policy to the population, forming a positive opinion of people about the foreign policy and neutralizing the negative perception of specific activities in this area. It is proved that only at the beginning of the 21st century did Spanish public opinion give preference to international events over domestic problems. Particular attention is focused on the facts of ignoring the public opinion of the opaque political actions of the governmental cabinet of Jose Aznar, who in 2002-2004 recognized the idea of a unipolar world, identified the Atlantic policy of the state as a priority, and supported the anti-Iraqi coalition and Iraqi coalition. It has been found that such a foreign policy caused an early election and a change of government. Political parties, autonomous governments, non-governmental organizations and individuals are identified as the key generators of public opinion in Spain's foreign policy. The mass media of the parliamentary monarchy play an important role in shaping public attitudes and influencing foreign policy.
\end{abstract}

Key words: Spain, foreign policy, public opinion, media.
Studies of public opinion and influence on the external course of Spain are actualized by the fact that the parliamentary monarchy is on the threshold of a new democratic transition. The longstanding economic and political crisis, corruption scandals, the Catalan problem require urgent reforms. The ruling elite declared its readiness to implement a new political and socio-economic modernization of the country, to strengthen territorial unity, to ensure the role of the Iberian state in European construction, to improve its progressive image in the world through an active foreign policy. In order to implement domestic and foreign policy, the monarchy's power institutions need the support of civil society and public opinion.

The interrelation of public opinion and foreign policy was investigated by well-known foreign theorists of the realist school - G. Almond, J. Baudrillard, P. Bourdieu, R. Dahrendorf, M. Weber, H. Lasswell, W. Lippmann, H. Morgenthau, O. Spengler and others. These scholars argued that public opinion, which is formed by powerful elites, is influenced by these elites who constantly manipulate it. Realists argued that the public has no substantial thought or organized interest in foreign policy since only the power structures are responsible for the implementation of state interests and possess the necessary information to make important foreign policy decisions.

In the asset of liberal theorists such as T. RisseCappen, B. Russet, J. Rosenau, B. Paige, R. Shapiro and others public opinion was recognized as consistent, structured, stable and rational, which can ensure control and accountability of politicians, improve social welfare. However, the eminent American scientist $O$. Holsti was right when he argued that public opinion on foreign policy is slowly finding its place as a subject of research through hostility from two currents: the realistic school of international relations and the "Almond-Lippman consensus" [14, p. 440-441].

Public opinion remains a social phenomenon an indicator of the democratization of society and the state in the modern world. Public opinion is seen as a reflection of the thinking, behavior and collective customs of citizens. The definition of public opinion as a discussion and expression of the public's points of view on issues of common interest aimed at the rest of society and especially the authorities by the famous Spanish political scientist C. Monson is noteworthy. He draws attention to the dynamic and conflicting nature of the discussion, the publicity of different points of view, which should be of interest to society and power structures. The scientist is sure that the polysemy of public opinion is rich and diverse in nuances because there are many angles, approaches and measurements on which it is based. At the same time, Monzon admits that public opinion is only the opinion of an elected, educated and powerful minority which thinks according to its own criteria and its own interests, and later, transmits its ideas to the rest of the population, which gives them as their 
thoughts: public and collective [15]. His compatriot, Professor J. Ferreres, considers public opinion as a communicative and psychosocial phenomenon that depends on the historical and socio-cultural context, the type of society and the political interests of the moment [10]. The Latin American scientist M. Mora came to the conclusion that individuals create consensuses and disagreements, adaptations and challenges, form images and perceptions, strengthen or contradict thoughts that permeate each era and combine them with each specific issue which acquires social relevance. When citizens talk to each other and spread their opinions in the social space, it contributes to the formation of an intangible fabric called public opinion [16, p. 23].

American researcher $\mathrm{H}$. Nieburg defined public opinion very peculiar. For him it is a term used to mask and mitigate the potential of conflict that arises as a result of different value systems. The use of "public opinion" legitimizes the continuation of dialogue and the formation of a position of openness and tolerance $[17$, p. 11].

Thus, scientists characterize the concept of "public opinion" in different ways. Well-known researcher E. Noelle-Neumann ironically commented on the attempts of scientists to define a concept that "increasingly expands until it becomes absolutely useless for practical purposes" [18, p. 83].

However, despite the considerable number of interdisciplinary studies of public opinion and influence on power institutions, it should be noted that there are few works that would study the public opinion of individual countries, its interaction with foreign policy (except for the United States and Britain).

Public opinion on foreign policy aims to understand the attitude of society to the international environment which is significantly different from domestic or national. As for the parliamentary monarchy, Iberian society has long been uninterested in foreign policy issues. View that the Spaniards lived with their backs to international politics has long been prevailing among scholars. It is confirmed by the Madrid Professor A. Barrio, who points out that the interest of ordinary Spaniards in the sphere of foreign policy and interstate relations was not a priority in the period of independence and "... it ranked last in the table of interests that covered such issues as social inequality, energy crisis, unemployment, morality in society, social security, public order, terrorism, regional autonomy" [2, p. 58].

The first democratic governments of $A$. Suarez (1976-1981), L. Calvo Sotelo (1981-1982) carried out democratic reforms changing the philosophy of foreign policy, forms and means of implementing international policy. The political elite of the country developed a communicative function explaining to the population the goals and objectives of foreign policy as required by democratic reforms. Officials and diplomats have repeatedly spoken in the Cortes Generales and foreign policy practice has been widely covered in the media. The opinion of people regarding the foreign policy course was formed through speeches in the legislature, print media, radio and television. According to a 1975 survey, $74 \%$ of citizens sought freedom of the press, $71 \%$ sought religious freedom and $58 \%$ sought trade union freedom [7, p. 10].

It is necessary to agree with the statement of Professor A. Hernandes: “... the success of the political elite of the time lay exclusively in its positive attitude to public thought, which forced the elites to practice dialogue and negotiation as an instrument of political action and adapted the language of public opinion to political discourse" [13, p. 40]

Spain concretized the principles and priorities of foreign policy on the basis of consensus between political parties by the end of the twentieth century. The commitment to European integration was based on the understanding that Madrid's active role in the European Union would be the best way to protect national interests. The manifestation of the country democratization becomes popular referendums through which the public expressed its attitude to certain political and social issues. Adopted by referendum decisions have acquired a decisive importance. The historic national referendum on the membership of the parliamentary monarchy in the North Atlantic Alliance was held on March 12, 1986. In this referendum $52.54 \%$ of Spaniards supported the extension of the state's stay in the bloc, $39.83 \%$ voted against, $6.54 \%$ abstained [1, p. 71$]$. The Cabinet of the Spanish workers' socialist party, headed by Prime Minister F. Gonzalez, solved the problematic issues of Spain's stay in NATO, given public opinion which tended to understand that the country's neutrality means continued international isolation. The ruling elite managed to influence the evolution of Spanish public opinion regarding the country's entry into the military-political Alliance and convince the public to change its opinion from anti-NATO to proNATO. In the future, all foreign policy issues related to the security and economic prosperity of the country have always led "to the effect of increasing public interest in international affairs" [6, p. 2].

A contradictory and confrontational foreign policy model was produced in 2002-2004 by the government Cabinet of J. Aznar without coordination in the General Cortes with the main political forces. The defining vector of foreign policy was the Atlantic; the priority was given to bilateral relations with the United States and unquestioning support for the policy of the administration of $G$. Bush. Public opinion for the first time gave an advantage to international events over domestic problems in 2002. Spaniards expressed solidarity with the United States because of the tragedy of September 11, 2001 related to terrorist acts. The war in Afghanistan, the Spanish-Moroccan 
incident on the island of Perejil, the Falklands crisis influenced Spanish public opinion which condemned international terrorism and illegal immigration.

Spanish public opinion did not support the decision of the government of J. Aznar to join the anti-Iraqi coalition, but the Cabinet openly ignored the pressure of citizens. According to the barometer of public opinion (BRIE), in November 2002, $61 \%$ of Spaniards opposed the USA invasion of Iraq and $24 \%$ said that any intervention should have the support of the UN. According to an opinion poll conducted in 2003, $65 \%$ of respondents opposed a military strike on Iraq even with the support of UN military action $[19$, p. 3].

The catalysts for the change of the government Cabinet and the return to power of the socialists were the terrorist attacks in Madrid on 11 March 2004, which killed hundreds of civilians, the opacity of the populist government and the deliberate disregard of public opinion. According to a BRIE poll in May 2004, $64 \%$ of Spaniards believed that terrorist attacks would not have taken place if Spain had not supported the US in the Iraq conflict. These attacks directly influenced the voters' decision to change the party in power [21, p. 12].

On May 21, 2004, the new PSOE Cabinet implemented its first political decision to withdraw Spanish troops from Iraq. "Spaniards should havevoted with their heads for the ruling Popular Party (achieved significant economic results), but the terrorists forced them to vote with their hearts", summed up $\mathrm{H}$. Noya [20]. The actions of the socialist government were also critically evaluated by the Iberian political analyst F. Portero, calling such a decision "...strengthening the strategy of radical Islamism and the dangerous moral disarmament of Spanish society in the face of the challenges that face it through the growing presence of anti-American and pacifist tendencies and, above all, an intense political campaign aimed at convincing the public that it is possible to avoid terrorist actions by avoiding intervention in the middle East and distancing itself from American politics" [23].

Spanish management system operates smoothly and efficiently today relying on many years of experience in making foreign policy decisions, their analysis, planning and coordination. Public authorities are responsible for the formation and implementation of the country's foreign policy. The systematic method of decision-making allows to identify the problem and political goals correctly, to compare different points of view, to take into account unpredictable consequences, to estimate the cost of actions, to predict possible consequences. It is appropriate to note that public opinion is not responsible for the actions of the state in the international arena but exists as an independent institution of a democratic society.

Theroleofthinkcenterswasespeciallystrengthened in the early 90-ies, when Spain became an influential country of the European Union determined its foreign policy priorities in the European, Euro-Atlantic,
Mediterranean, Latin American directions. They began to play an important role in shaping public opinion and political decision-making processes and became the country's informal analytical diplomacy. Some think tanks influence the political process in the long run, changing political elites and public opinion. The potential influence of the centers on the political process is heterogeneous: it can be direct when the party becomes ruling and indirect when the party is in opposition limiting participation in debates on a particular issue in the media and trying to change public opinion. The main goal of the leading think center of the parliamentary monarchy, the Royal Institute of ELCANO, is to create a forum for the exchange of views on international issue.

The extraordinary consistency is demonstrated by the public opinion of Spain regarding news related to the EU, the US and LatinAmerican countries. The process of European integration has always been perceived as an absolute priority of Spanish foreign policy. The main advantages of membership in the European community Spaniards consider economic well-being (39\%), the possibility of creating new jobs (23\%), improving cooperation between member States (22\%), improving living standards (22\%), peace and prosperity (21\%). Public opinion in Spain identified EU membership as a priority in international Affairs (63\%). $90 \%$ of Spanish citizens vote for the free movement of EU citizens who can live, work, study and do their business anywhere in Europe, for a common defense and security policy among EU member States are $82 \%$, for a common energy policy among EU member States are $81 \%$, for a common EU trade policy are $80 \%$, for a common European policy on migration are $82 \%$, for a common foreign policy of $28 \mathrm{EU}$ member States are $78 \%$, for a single digital market in the EU are $71 \%$, for a European economic and monetary Union with one single currency, the euro are $76 \%$, for further the EU enlargement are $67 \%[7$, p. 65].

Public opinion evaluated differently relations with the United States and the countries of Iberoamerica in different years. Under the presidency of G.W. Bush in 2005-2007, relations with the superpower were not considered a priority of Spanish public thought which preferred relations with Latin American countries. After the election of us President B. Obama in 2008, interest in relations with this country has significantly increased, but its decline in relation to the policy of Latin American States has been traced. It should be noted that such differences are influenced by ideological and political attitudes. Thus, citizens with left-wing positions of the ideological spectrum give priority to relations with Latin America; centrists and right-wing relations with the United States. This combination of political ideology with positioning in favor of a particular foreign policy option is a constant for Iberian public opinion and does not go beyond the political conjuncture of the moment. 
Close neighbors-Moroccans for decades associated with the images of "barbarians", "infidels" in the public opinion of Spaniards, and in recent yearswith the problems of the Spanish enclaves of Ceuta and Melilla in North Africa, the conflict on the island of Perehil (2002), illegal migration, disputes with fishing and more. Until now, school textbooks, folk tales, movies, fiction and the press of Spain contribute to the preservation of the negative perception of Morocco and Moroccans [12, p. 23-29].

In terms of mutual perception, a sharp dichotomy has emerged between how the Spanish elite and the common people view the People's Republic of China. According to a sociological survey conducted in 2006, $45 \%$ of respondents believed that China's influence in the world is positive. However, the attitude of Spaniards to China deteriorated sharply with the onset of the international economic crisis. Thus, the percentage of negative views of Iberians was the highest among the 5 largest EU economies in 2013. Due to widespread perceptions, Chinese competition is blame for the loss of a significant number of jobs by Spanish citizens [8, p. 382-383].

At the beginning of the century, digital diplomacy was formed as a component of political culture and human interaction. The public realized the importance of new effective methods of diplomacy that went beyond official political institutions. Social networks contributed to the effective exchange of views between politicians and civil society, improved the ability of foreign professionals to collect and analyze the necessary information, predict and respond to foreign policy events. Ordinary citizens react more actively to information flows and engage in political dialogue by joining global social groups that are not limited by state borders. Social media and networks have become a real reflection of the aspirations and needs of citizens; they form public opinion, views and moods; help the process of creating a two-way relationship with the authorities. The media and social networks influence the relationship between public opinion and foreign policy by being able to assume an alternative role between passively communicating messages from decision makers and making public requests for information. In addition, the media can expand or reduce the amount of information covering a certain foreign policy event or situation which can change the content of public opinion [3, p. 56-62].

Gradually, public opinion became an independent institution, a factor of influence on various spheres of political and public life. The main channels of expression of public opinion are: elections, distribution of power structures into legislative and executive, civil rights and freedoms guaranteed by the state including universal suffrage, freedom of speech, and participation of citizens in referendums on certain issues as well as the activities of the mass media [22, p. 117-119].
The institution of the monarchy has long served as a symbol of national unity and stability. The Spanish media almost did not criticize the institution of the monarchy and created a media image of the King "as a secular Saint of Spain" in the period of transit and consolidation of democracy. However, corruption scandals involving members of the Royal family have undermined the foundations of the monarchy and caused discontent in society. There are trends towards a new democratic rationalization of the political system and republicanism in modern Spanish society. In addition, 7 out of 10 Spaniards under the age of 40 do not support the monarchy. According to the Spanish center for sociological research on the values of the 1978 Constitution, only 5 percent of respondents claimed that one of the benefits was the restoration of the monarchy [9].

The modern public is more aware of international events and is interested in their solution. Citizens are not isolated from political processes in the globalized world. Ordinary citizens vote for parties that have attractive foreign policy and foreign economic platforms, charismatic political leaders. Public opinion influences foreign policy by choosing political parties and leaders who share the public interest and are competent in international affairs.

As a conclusion, modern social thought in Spain is able to ensure the stability and evolution of public life, the integration of aspirations and interests of ordinary citizens actively responding to the actions of representatives of the power structures of the country. Modern social thought can assess ability or inability of regional entities to reform and improve the spheres of life of people to implement foreign policy. Every citizen of democratic Spain is free to express their own point of view on a particular issue today. The level of competence of public opinion is supported by influential media and powerful non-state think tanks.

\section{BIBLIOGRAPHY:}

1. Alicio y satisfaccion en occidente por el resultado favorable del referendum (1986) ABC. 13 de marzo de 1986. P. 71.

2. Barrio Marquina A. (1985). Opinión pública y política exterior en España. Opinion publique et politique extérieure en Europe. III. 1940-1981. P. 41-58.

3. Baum A. Matthew \& Potter B.K. Philip. (2008) The Relations Between Mass Media, Public Opinion, and Foreign Policy: Toward a Theoretical Synthesis. Annual Revie Political Science. No. 11. P. 39-65.

4. Blasco-Duatis M., Fernández García N. \& Cunha I. (2017). Political opinion in the Spanish newspapers. Revista Latina de Comunicación Social. No. 72. P. 349-373.

5. Capellan de Miguel G. (2010). La opinion Secuestrada Prensa y Opinion Publica en el siglo $\mathrm{XIX}$. Berceo. Revista riojana de ciencias sociales y humanidades. No. 159. P. 3-62.

6. Capellán de Miguel G. \& Pérez Serrano J. (Eds.) (2008). Sociedidad de masas, medios de comuncacion y opinin publica. $372 \mathrm{p}$. 
7. Chislett W. (2018). Forty years of democratic Spain. Political, economic, foreign policy and social change, 1978-2018. Real Instituto Elcano. Royal Instituto. Working Paper. Documento de Trabajo. 2018. 92 p.

8. Esteban M. (2016). Spain's Relations with China; Friends but not Partners. Chinese Political Sciences Revie. No. 1. P. 373-386.

9. Fernandes Ramos F. (2013). The monarchy, a journalistic taboo in Spain. Revista Latina de Comunicacion Social. P. 209-240.

10. Ferreres Rubio J.M. (2009). Opinión pública y medios de comunicación. Teoría de la agenda setting Public opinion and mass media. Gazeta de Antropología, No. 25 (1). URL: http://hdl.handle.net/10481/6843.

11. González Alonso M. (2016). Opinión pública y web 2.0. Revista Mexicana de Opinión Pública. P. 95-113.

12. González García E., García Muñiz A., García Sansano J. \& Iglesias Villalobos L. (Coords.) (2015). Mundos emergentes: cambios, conflictos y expectativas. Toledo : ACMS. P. 22-30.

13. Hernandez Sanchez A. (2010). La opinión pública española en la transición del franquismo a la democracia. Revista de Investigaciones Políticas y Sociológicas (RIPS). P. 39-69.

14. Holsti Ole R. (1992). Public Opinion and Foreign Policy: Challenges to the Almond-Lippmann Consensus. International Studies Quarterly. Vol. 36 (4). P. 439-466.

15. Monzon Arribas C. (1990). La opinión pública. Teoría, concepto y métodos. Tecnos. Madrid, 1990. 207 p.

16. Mora y Araujo M. (2005). El poder de la conversación. Elementos para una teoría de la opinión pública. Buenos Aires : La Crujía Ediciones. 660 p.

17. Nieburg H. (1984). Public Opinion, New York : Praeger Publishers. 287 p.

18. Noelle-Neumann, E. (2003). La espiral del silencio. Opinión pública: nuestra piel social. Barcelona, Paidós, 336 p.

19. Noya J. (2003). La Guerra de la opinion publica. Analyses of the Elcano Royal Institute (ARI). № 34/2003.

20. Noya J. (2004). Del 11-M al 14-M: estrategia yihadista, elecciones generales y opinion publica. Analyse so the Elcano Royal Institute (ARI). № 132/2004.

21. Noya J. (2005). Del 92 Alianza de Civilizaciones: Cumbres Abismales en la Imagen Exterior de Espana. Documento de Trabajo (DT) 36/ Agosto. P. 3-17.

22. Torcal M. \& Martini S. (ed.) (2018). Opinión pública y cambio electoral en España: claves ante el reto europeo y la crisis política y económica. Colección Academia. Madrid, 246 p.

23. Portero F. (2004). Sobre el mal de altura: política exterior, opinión pública y lucha contra el terrorismo. Analyses of the Elcano Royal Institute (ARI). 88/2004.

\section{REFERENCES:}

1. Alicio y satisfaccion en occidente por el resultado favorable del referendum (1986) ABC. 13 de marzo de 1986. P. 71.

2. Barrio Marquina A. (1985). Opinión pública y política exterior en España. Opinion publique et politique extérieure en Europe. III. 1940-1981. P. 41-58.

3. Baum A. Matthew \& Potter B.K. Philip. (2008) The Relations Between Mass Media, Public Opinion, and Foreign Policy: Toward a Theoretical Synthesis. Annual Revie Political Science. No. 11. P. 39-65.
4. Blasco-Duatis M., Fernández García N. \& Cunha I. (2017). Political opinion in the Spanish newspapers. Revista Latina de Comunicación Social. No. 72. P. 349-373.

5. Capellan de Miguel G. (2010). La opinion Secuestrada Prensa y Opinion Publica en el siglo XIX. Berceo. Revista riojana de ciencias sociales $y$ humanidades. No. 159. P. 3-62.

6. Capellán de Miguel, G. \& Pérez Serrano, J. (Eds.) (2008). Sociedidad de masas, medios de comuncacion y opinin publica. $372 \mathrm{p}$.

7. Chislett W. (2018). Forty years of democratic Spain. Political, economic, foreign policy and social change, 1978-2018. Real Instituto Elcano. Royal Instituto. Working Paper. Documento de Trabajo. 2018. 92 p.

8. Esteban M. (2016). Spain's Relations with China; Friends but not Partners. Chinese Political Sciences Revie. No. 1. P. 373-386.

9. Fernandes Ramos F. (2013). The monarchy, a journalistic taboo in Spain. Revista Latina de Comunicacion Social. P. 209-240.

10. Ferreres Rubio J.M. (2009). Opinión pública y medios de comunicación. Teoría de la agenda setting Public opinion and mass media. Gazeta de Antropología. No 25 (1). URL: http://hdl.handle.net/10481/6843.

11. González Alonso M. (2016). Opinión pública y web 2.0. Revista Mexicana de Opinión Pública. P. 95-113.

12. González García E., García Muñiz A., García Sansano J. \& Iglesias Villalobos L. (Coords.) (2015). Mundos emergentes: cambios, conflictos y expectativas. Toledo : ACMS. P. 22-30.

13. Hernandez Sanchez A. (2010). La opinión pública española en la transición del franquismo a la democracia. Revista de Investigaciones Políticas y Sociológicas (RIPS). P. 39-69.

14. Holsti Ole R. (1992). Public Opinion and Foreign Policy: Challenges to the Almond-Lippmann Consensus. International Studies Quarterly. Vol. 36 (4). P. 439-466.

15. Monzon Arribas C. (1990). La opinión pública. Teoría, concepto y métodos. Tecnos. Madrid, 1990. $207 \mathrm{p}$.

16. Mora y Araujo M. (2005). El poder de la conversación. Elementos para una teoría de la opinión pública. Buenos Aires, La Crujía Ediciones, 660 p.

17. Nieburg H. (1984). Public Opinion, New York : Praeger Publishers. $287 \mathrm{p}$.

18. Noelle-Neumann E. (2003). La espiral del silencio. Opinión pública: nuestra piel social. Barcelona : Paidós. $336 \mathrm{p}$.

19. Noya J. (2003). La Guerra de la opinion publica. Analyses of the Elcano Royal Institute (ARI). № 34/2003.

20. Noya J. (2004). Del 11-M al 14-M: estrategia yihadista, elecciones generales y opinion publica. Analyse so the Elcano Royal Institute (ARI). № 132/2004.

21. Noya J. (2005). Del 92 Alianza de Civilizaciones: Cumbres Abismales en la Imagen Exterior de Espana. Documento de Trabajo (DT) 36/ Agosto. P. 3-17.

22. Torcal M. \& Martini S. (ed.) (2018). Opinión pública y cambio electoral en España: claves ante el reto europeo y la crisis política y económica. Colección Academia. Madrid, 246 p.

23. Portero F. (2004). Sobre el mal de altura: política exterior, opinión pública y lucha contra el terrorismo. Analyses of the Elcano Royal Institute (ARI). 88/2004. 


\section{Вплив громадської думки на зовнішню політику Іспанії у XXI столітті}

Матлай Любава Сергіївна

кандидат історичних наук, асистент кафедри політології та міжнародних відносин Національного університету «Львівська політехніка» вул. Митрополита Андрея, 5, Львів, Україна
Mema дослідження - розкрити вплив громадської думки на фрормування та реалізацію зовнішньої політики Іспанії, розглянути взаємодію суб'єктів прийняття зовнішньополітичних рішень. Методологія дослідження спирається на міждисциплінарний підхід. Застосування принципу історизму дало змогу дослідити конкретно-історичні зовнішньополітичні ситуації та їх сприйняття громадською думкою парламентської монархії. Відповідно до принципу динаміки та розвитку відображається еволюція формування громадської думки іберійців. Уперше представлено та охарактеризовано окремі теоретичні праці іспанських науковців щодо громадської думки з питань зовнішньої політики та міжнародних відносин. Досліджено особливості громадської думки в окремій середній європейській державі з глобальними інтересами. Можна стверджувати, що інтерес пересічних іспанців до сорери зовнішньої політики та міждержавних відносин тривалий час не був пріоритетним. Перші урядові кабінети демократичної Іспанії змінили фрілософрію зовнішньополітичної діяльності, форми та засоби реалізації міжнародної політики, розвиваючи комунікативну функцію, пояснюючи населенню цілі та завдання зовнішньої політики, фрормуючи позитивну думку людей щодо зовнішньополітичного курсу та нейтралізуючи негативне сприйняття конкретних заходів у зазначеній сфрері. Доведено, що лише на початку XXI століття іспанська громадська думка надала перевагу міжнародним подіям над внутрішніми проблемами. Особлива увага зосереджена на фрактах ігнорування громадською думкою непрозорих політичних дій урядового кабінету Х.М. Аснара, який у 2002-2004 рр. визнав ідею однополярного світу, визначив пріоритетним атлантичний напрям зовнішньої політики держави, підтримав антиіракську коаліцію та направив в Ірак іспанський збройний контингент. З'ясовано, що такий зовнішньополітичний курс народників спричинив дострокові вибори та зміну влади. Встановлено, що ключовими генераторами громадської думки в зовнішній політиці Іспанії є політичні партії, уряди автономії, громадські організації та окремі громадяни. Засоби масової інфрормації парламентської монархії відіграють важливу роль у фрормуванні суспільного ставлення та впливу на зовнішню політику. Ключові слова: Іспанія, громадська думка, зовнішня політика, медіа. 